\title{
Г.І. Іщенко
}

\section{Альтернативні методи у веденні прееклампсії. Аналітичний огляд}

\author{
ДУ «Інститут педіатрії, акушерства і гінекології імені академіка О.М. Лук'янової НАМН України», м. Київ
}

Ukrainian Journal of Perinatology and Pediatrics. 2021.3(87): 56-63; doi 10.15574/PP.2021.87.56

For citation: Ischenko Gl. (2021). Alternative methods in the management of preeclampsia. Analytical inspection. Ukrainian Journal of Perinatology and Pediatrics. 3(87): 56-63. doi 10.15574/PP.2021.87.56

Зростає обсяг досліджень щодо виявлення нових терапевтичних засобів для профрілактики та лікування прееклампсії — препаратів, які можуть впливати на основну патофізіологію захворювання. Ці препарати діють на окислювальний стрес, антиангіогенні фактори, а також ангіотензин, оксид азоту й різноманітні ланки запального процесу. Таким чином, вони впливають на захворювання плаценти або ендотелію. Запропоновані методи лікування наразі проходять доклінічні та клінічні випробування. Серед них найбільший інтерес викликав правастатин. Існують доклінічні дослідження, які свідчать про його плейотропну дію - вплив на множинні молекулярні мішені, завдяки чому доведено на тваринних моделях його ефективність щодо прееклампсії. Інгібітори протонної помпи, метформін та сульфасалазин — це інші препарати, що мають доклінічні докази множинних молекулярних дій, які можуть вирішити патофізіологію прееклампсії. Нещодавно проведено багато доклінічних досліджень, що виявляють потенціал численних природних сполук для лікування прееклампсії, таких як рослинні екстракти та мікроелементи, що мають потужну протизапальну або антиоксидантну активність. Іншим напрямом стали нові молекулярно-орієнтовані стратегії - моноклональні антитіла, спрямовані на фрактор некрозу пухлини альфра, фрактор росту плаценти і технологію коротких інтерференційних РНК, щоб загальмувати експресію генів розчинної fms-подібної тирозинкінази-1 або ангіотензиногену. Інші підходи до лікування, які перейшли на випробування на людях (починаючи від досліджень з однією групою до випробувань фази III, які завершені або тривають), включають фолієву кислоту, донори оксиду азоту (такі як L-аргінін), рекомбінантний антитромбін III, імуногенний антиген дигоксину і мелатонін. Були серії випадків, які показують, що видалення розчинної fms-подібної тирозинкінази-1 може допомогти стабілізувати захворювання та продовжити вагітність. $€$ повідомлення про випадки, які вказують на те, що моноклональні антитіла, такі як екулізумаб (інгібітор комплементу) можуть мати терапевтичний потенціал. Отже, виявлені альтернативні препарати у лікуванні та профілактиці прееклампсії створюють потенціал для поліпшення здоров'я матері та перебігу вагітності.

Автор заявляє про відсутність консрлікту інтересів.

Ключові слова: прееклампсія, вагітність, правастатин, метформин, сульфралазин.

\section{Alternative methods in the management of preeclampsia. Analytical inspection G.I. Ischenko \\ SI «Institute of Pediatrics, Obstetrics and Gynecology named by academician O.M. Lukyanova of the NAMS of Ukraine», Kyiv}

There are many alternative drugs for the prevention and treatment of preeclampsia in the new research. This drugs can effect on the underlying pathophysiology of the disease: oxidative stress, antiangiogenic factors, as well as angiotensin, nitric oxide and various parts of the inflammatory process. Thus, they affect the disease of the placenta or endothelium. The proposed treatments are currently undergoing preclinical and clinical trials. Pravastatin was of the greatest interest among all the proposed therapeutic agents. It has pleiotropic effect, i.e. affects multiple molecular targets against preeclampsia. Proton pump inhibitors, metformin, and sulfasalazine are other drugs that have preclinical evidence of multiple molecular actions that may address the pathophysiology of preeclampsia. Currently, these molecules are also in clinical trials. Many natural compounds for the treatment of preeclampsia, such as plant extracts and trace elements, are being researched to identify the potential in anti-inflammatory or antioxidant activity. Monoclonal antibodies are another direction is new molecular-oriented strategies. They are targeting tumor necrosis factor alpha, placental growth factor and short interfering RNA technology to inhibit the expression of soluble fms-like tyrosine kinase-1 or angiotensinogen. Folic acid, nitric oxide donors (such as L-arginine), recombinant antithrombin III, and immunogenic digoxin antigen and melatonin are other treatment approaches that have been tested in humans (ranging from single-group studies to phase III trials that have been completed or are ongoing). The series of cases demonstrated that removal of circulating soluble fms-like tyrosine kinase-1 can help stabilize the disease and prolong pregnancy. Monoclonal antibodies such as eculizumab (a complement inhibitor) may have therapeutic potential. Thus, the identified alternative drugs in the treatment and prevention of preeclampsia create the potential to improve maternal health and pregnancy.

No conflict of interests was declared by the author.

Key words: preeclampsia, pregnancy, pravastatin, metformin, sulfalazine.

\section{Альтернативные методы в ведении преэклампсии. Аналитический обзор А.и. Ищенко \\ ГУ «Институт педиатрии, акушерства и гинекологии имени академика Е.М. Лукьяновой НАМН Украины», г. Киев}

Увеличивается объем исследований по выявлению новых терапевтических средств для профилактики или лечения преэклампсии - препаратов, которые могут влиять на основу патофизиологии заболевания. Эти препараты действуют на окислительный стресс, антиангиогенные факторы, а также ангиотензин, оксид азота и различные звенья воспалительного процесса. Таким образом, они влияют на заболевания плаценты или эндотелия. Предложенные методы лечения в настоящее время проходят доклинические и клинические испытания. Среди всех предложенных терапевтических средств наибольший интерес вызвал правастатин. Существуют доклинические исследования, подтверждающие его плейотропное действие - влияние на множественные молекулярные мишени, благодаря чему доказано на животных моделях его эфффективность при преэклампсии. Другими препаратами с аналогичным действием в патофизиологии преэклампсии являются ингибиторы протонной помпы, метформин и сульфрасалазин. Недавно проведено много доклинических исследований, выявляющих потенциал многочисленных природных соединений для лечения преэклампсии, таких как растительные экстракты и микроэлементы, обладающие мощной противовоспалительной или антиоксидантной активностью. Также новым направлением стали молекулярно-ориентированные стратегии - моноклональные антитела, направленные на фактор некроза опухоли альфа, фрактор роста плаценты и технологию коротких интерферирующих РНК, чтобы затормозить экспрессию генов растворимого fms-образной тирозинкиназы-1 или ангиотензиногена. На этап клинических исследований перешли другие подходы к лечению, включающие фролиевую кислоту, доноры оксида азота (такие как L-аргинин), рекомбинантный антитромбин III, иммуногенный антиген дигоксина и мелатонин. Были серии случаев, демонстрирующих, что удаление циркулирующей растворимого fms-образной тирозинкиназы-1 может помочь стабилизировать заболевание и продлить беременность. Также ученые сообщают о терапевтическом потенциале моноклональных антител, таких как экулизумаб (ингибитор комплемента). Таким образом, в лечении и профилактике преэклампсии обнаружены альтернативные препараты, представляющие потенциал для улучшения здоровья матери и течения беременности.

Автор заявляет об отсутствии конфрликта интересов.

Ключевые слова: преэклампсия, беременность, правастатин, метформин, сульфалазин. 


\section{Вступ}

$\{$ ростає обсяг досліджень щодо виявлення ○асобів для профітів, які можуть впливати на основну патофізіологію захворювання. Ці препарати діють на окислювальний стрес, антиангіогенні фактори, а також ангіотензин, оксид азоту і різноманітні ланки запального процесу. Таким чином, вони впливають на захворювання плаценти або ендотелію. Запропоновані методи лікування наразі проходять доклінічні та клінічні випробування. Серед запропонованих терапевтичних засобів найбільший інтерес викликав правастатин. Існують доклінічні дослідження, які свідчать про його плейотропну дію, тобто вплив на множинні молекулярні мішені, завдяки чому доведено на тваринних моделях його ефективність щодо прееклампсії. Інгібітори протонної помпи, метформін та сульфасалазин - це інші препарати, що мають доклінічні докази множинних молекулярних дій, які можуть вирішити патофізіологію прееклампсії. На сьогодні ці молекули також оцінюються в клінічних випробуваннях. Нещодавно проведено багато доклінічних досліджень, що виявляють потенціал численних природних сполук для лікування прееклампсії, таких як рослинні екстракти та мікроелементи, які мають потужну протизапальну або антиоксидантну активність. Іншим напрямом стали нові молекулярно-орієнтовані стратегї - моноклональні антитіла, спрямовані на фактор некрозу пухлини альфа, фактор росту плаценти та технологію коротких інтерференційних РНК, щоб загальмувати експресію генів розчинної fms-подібної тирозинкінази-1 або ангіотензиногену. Інші підходи до лікування, що перейшли на випробування на людях (починаючи від досліджень 3 однією групою до випробувань фази III, які завершені або тривають), включають фолієву кислоту, донори оксиду азоту (такі як L-аргінін), рекомбінантний антитромбін III, імуногенний антиген дигоксину і мелатонін. Були серії випадків, які свідчать, що видалення розчинної fms-подібної тирозинкінази-1 може допомогти стабілізувати захворювання та продовжити вагітність. Існують повідомлення про випадки, які вказують на те, що моноклональні антитіла, такі як екулізумаб (інгібітор комплементу), можуть мати терапевтичний потенціал. Отже, виявлено альтернативні препарати в лікуванні та профілактиці прееклампсії, що створюють потенціал для поліпшення здоров'я матері та перебігу вагітності. Прееклампсія є складним розладом вагітності, який спостерігається приблизно від 3\% до 5\% вагітностей $[1,4]$. На відміну від більшості основних ускладнень вагітності, вона становить загрозу як жінці, так і плоду [27], а їі наслідки в матері можуть тривати протягом десятків років (підвищення ризику серйозних серцево-судинних захворювань [42,23] та дитини (підвищення ризику хронічних вад та відставання в розвитку внаслідок обмеження росту плода та недоношеності).

Однозначно ефективним препаратом є аспірин. Однак навіть він не може дати гарантованих результатів для повного лікування захворювання. Під час аналізу 60 досліджень за участю 36716 учасників зроблено висновок, що аспірин зменшує протеїнурію приблизно на 18\% (відносний ризик $[\mathrm{RR}]=0,82 ; 95 \%$ довірчий інтервал $[\mathrm{CI}]=0,77-0,88)$. Також досить ефективним є профілактичне призначення кальцію при прееклампсії $[9,10]$. Окрім цього, в лікарській практиці ефективним виявилося призначення низькомолекулярних гепаринів. Водночас постає нагальна потреба визначити нові терапевтичні засоби для допомоги вагітним $з$ прееклампсією.

\section{Патогенез прееклампсіі}

Прееклампсія перебігає у два етапи. На першій стадії погана плацентація призводить до плацентарної гіпоксії, ішемічно-реперфузійної травми, плацентарного окислювального стресу та прозапальної реакції. Наступним етапом плацента реагує, виділяючи надмірну кількість розчинних факторів (особливо антиангіогенних факторів), які потрапляють у материнський кровообіг і спричиняють дисфункцію ендотелію та судинні травми. Потім це викликає гіпертонію і системне ураження органів матері. У судинах спостерігається прозапальна реакція та системний окислювальний стрес, зменшення вивільнення оксиду азоту та посилення активаціï ренін-ангіотензинового шляху. Новим поглядом стало виявлення білків як патологічних ланок розвитку прееклампсії [45], які стали новими маркерами їі розвитку. Причиною ендотеліальної дисфункції при гестації є порушення балансу про- та антиангіогенних індукторів, відповідальних за формування плаценти та процесу імплантації. Проангіогенні індуктори представлені судинним ендотеліальним фактором зростання (VEGF) й індуктором зростання плаценти (PlGF), антиангіогенні індуктори розчиною fms-подібною тирозинкіназою; 


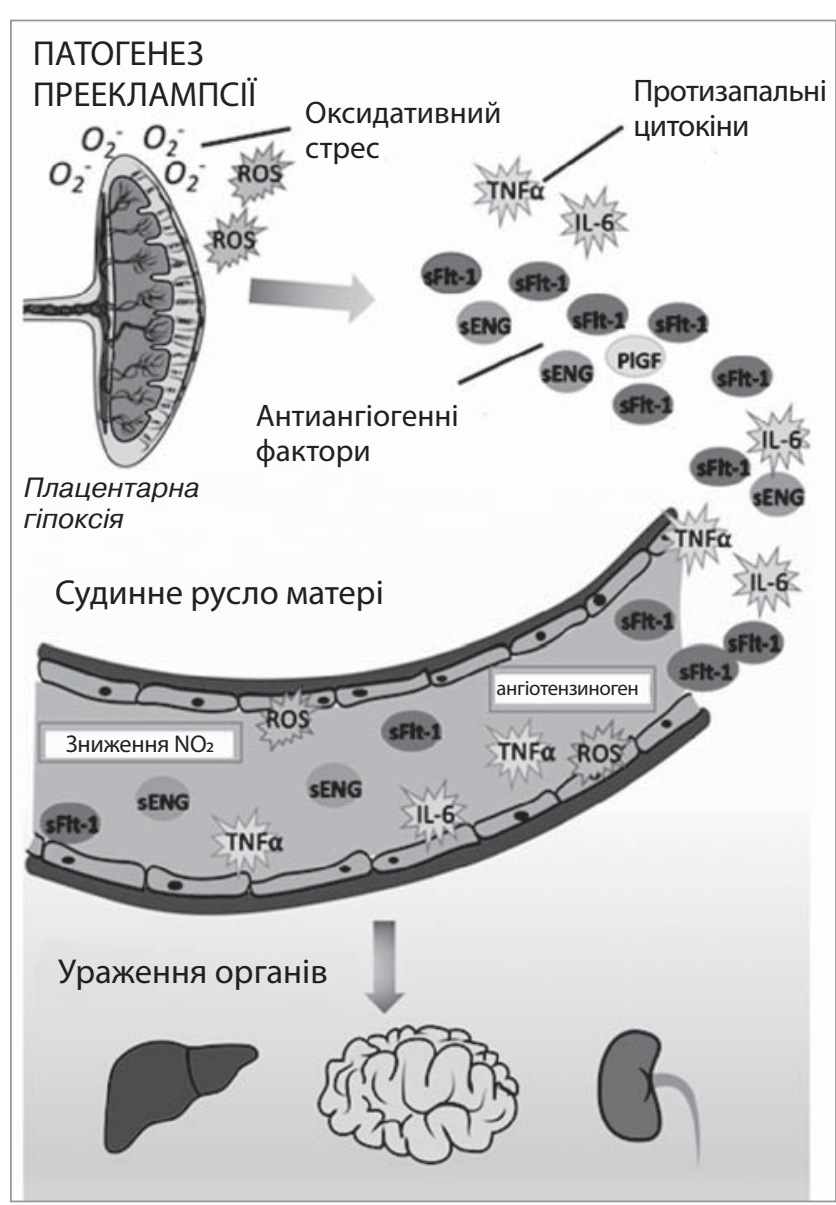

Pис. Патогенез прееклампсії (Tong et al., AMJOG, 2020)

1 (sFlt; 1) і ендогліном (sEng) [4]. 3 усіх розчинних факторів антиангіогенний фактор sFlt-1, імовірно, є основним фактором порушення функції ендотелію та пошкодження судин (рис.).

\section{Правастатин}

Правастатин - це ліпідознижувальний препарат, який широко застосовують для зменшення ризику серцево-судинних подій [44]. За останнє десятиліття йому надавали значної уваги в лікуванні прееклампсії після традиційних препаратів.

In vitro введення правастатину в тканини або клітини плаценти регулює антиоксидантні шляхи й може сприяти розвитку сприятливого ангіогенного профілю, зменшуючи секрецію sFlt-1 та sEng. Існують також експериментальні докази in vitro, що він усуває дисфункцію ендотелію, зокрема, зменшує експресію молекул адгезії судинних клітин першого типу (VCAM-1) і ET-1 та адгезію лейкоцитів на ендотеліальних клітинах, а також збільшує міграцію й адгезію ендотеліальних клітин [9]. Це означає, що правастатин сприятливо діє на судини як плаценти, так і матері.

У багатьох дослідженнях доведено, що правастатин усуває гіпертонію та протеїнурію при прееклампсії [28]. Правастатин знижує рівень sFlt-1, зменшуючи запалення і підвищуючи регуляцію синтази оксиду азоту (фермент в ендотелії, що утворює оксид азоту).

Лікування за допомогою правастатину під час вагітності потенційно може поліпшити віддалені результати після вагітності. Правастатин, призначений під час вагітності, зупиняе розвиток гіпертонії, забезпечує ремоделювання лівого шлуночка та усуває ураження нирок у матері [12].

Введення правастатиту під час вагітності та за 28 діб після пологів усуває серцево-судинну дисфункцію. Це підтверджено на тваринних моделях ехокардіографічно та гістологічно зменшилися гіпертрофія серця та інтерстиціальний фіброз [18].

Також провели випробування правастатину на ранніх стадіях [8]: 20 учасникам з передчасним гестозом в анамнезі вводили 10 мг правастатину або плацебо (на 12-16-му тижнях вагітності). У 4 з 10 учасників, які отримували плацебо, розвинулася прееклампсія, проте її не виявили серед тих, хто отримував правастатин. Правастатин є досить безпечним через короткий період напіввиведення, який становить 2-3 години.

Вчені [22] провели дослідження серед 11 учасників з антифосфоліпідним синдромом, які отримували 20 мг правастатину щодня, i порівняли їх з 10 учасниками, які не отримували препарату. Різниця в клінічних результатах була разючою - лише 6 з 11 новонароджених, які отримували плацебо, вижили, тоді як усі 11 учасників з групи правастатину народилися живими в термін. Також отримали дані ультразвукового дослідження (УЗД), які показують, що правастатин поліпшує матковий кровотік (серійні УЗД, виконані принаймні за тиждень, показали покращення середнього індексу пульсації маткових артерій для всіх 11 учасників, які отримували правастатин). Попри суттєву ефективність, ці дані потребують грунтовніших підтверджень.

Щодо правастатину провели 1 рандомізоване дослідження. Статистичне дослідження для полегшення раннього початку прееклампсії (StAmP) було багатоцентровим випробуванням у Великій Британії, де 40 мг щоденного правастатину або плацебо вводили 62 учасникам 3 прееклампсією, діагностованою на 24-31-му тижнях вагітності. У первинних даних виявили зниження sFlt-1 у плазмі крові 
за 3 доби після рандомізації. Правастатин не впливав на перинатальні результати. У серії з 4 жінок з передчасною прееклампсією правастатин (40 мг/добу) стабілізував рівень циркулюючого рівня sFlt-1 [9].

Спочатку правастатину присвоїли категорію X. Це передбачає, що його слід уникати під час вагітності. Однак пізніше вчені дійшли висновку, що не існує зв'язку між аномаліями плода та пренатальним введенням правастатину, хоча кількість вагітностей у жінок, яким вводили правастатин, становила лише 500-600, а це означає, що досі дослідження можуть бути недостатніми для виявлення підвищеного ризику структурних аномалій. Токсикологічні дослідження на тваринах показали, що препарат безпечний: правастатин не виявляється [8]. а якщо виявляється, то в дуже низьких концентраціях [2] у пуповині при народженні. А дослідження перфузії плаценти засвідчили, що може відбуватися активний відтік препарату назад. Однак, враховуючи, що мозок плода розвивається, дитячий організм може бути чутливим до препаратів, спрямованих на метаболізм ліпідів. Існують дослідження in vitro, які свідчать, що правастатин може збільшити загибель у нервових стовбурових клітинах плода миші [6]. На основі цього очевидно, що метою подальших досліджень правастатину має стати здоров'я новонароджених.

\section{Інгібітори протонної помпи (ІІП)}

ІПП широко застосовують для полегшення симптоматичного рефлюксу шлункової кислоти шляхом зменшення секреції кислоти, у тому числі під час вагітності. У доклінічних дослідженнях доведено [29], що, подібно до правастатину, ІПП (лансопразол, рабепразол та езомепразол) можуть зменшувати вивільнення sFlt-1 та sEng у плаценті in vitro (у разі менших концентрацій, ніж правастатин). Вони також зменшують вироблення плацентарних і судинних запальних цитокінів та пом'якшують дисфункцію ендотелію (зменшення експресії VCAM-1 та ET-1, зменшення адгезії лейкоцитів та посилення проліферації ендотеліальних клітин і формування ендотеліальної трубки). Езомепразол може поліпшувати судинну динаміку, оскільки каталізує фосфорильовану синтазу оксиду азоту в ендотеліальних клітинах (фермент, що продукує потужний оксид азоту), а також чинить судинорозширювальну дію на кровоносні судини черевної порожнини людини ex vivo (отримані дані при кесаревому розтині).
ІПП добре переносяться. Окрім цього, є масштабні дані, що підтверджують відсутність тератогенного ризику навіть у разі застосування в першому триместрі [26]. Дослідники [19] виявили взаємозв'язок між пренатальним впливом та астмою в дітей, але незрозуміло, чи він причинно-наслідковий, чи причиною можуть бути зовсім інші фактори.

Жінки 3 підтвердженою або підозрюваною прееклампсією, які застосовували інгібітори протонної помпи, мали сприятливий ангіогенний профіль (Зниження sFlt-1, sEng та ET-1) порівняно з тими, хто не отримував цих препаратів [35]. В епідеміологічному дослідженні з 157720 вагітностей [15] жінки застосовували ІПП 3 інших, відмінних від прееклампсії показань. Дані шведської когорти дали неоднозначну картину: 55 жінок, які випадково отримували ІПП, насправді мали підвищений ризик гестозу (скоригований коефіцієнт шансів, але знижений ризик передчасної прееклампсії, діагностованої в терміні гестації <37 тижнів $(\mathrm{aOR}=0,63 ; 95 \% \mathrm{CI}=0,41-0,96)$ або гестації <34 тижні (aOR =0,41; 95\% CI =0,20-0,82).

У дослідженні, в якому рандомізували 120 жінок з діагнозом раннього гестозу в термін вагітності від 26 до 32 тижнів до 40 мг щодобового застосування езомепразолу або плацебо, середне продовження гестації становило 11,4 доби (інтерквартильний діапазон [IQR] 3,6-19,7) у групі езомепразолу та 8,3 доби (IQR 2,8-19,6) серед тих, хто отримував плацебо. Таким чином, різниця між плацебо та емепразолом була незначною і становила 3 доби (95\% CI = 2,9-8,8; P=0,31). Вчені роблять висновок, що 40 мг езомепразолу не усуває раннього гестозу, проте його застосування для профілактики потребує вивчення. Також у фармакокінетичному дослідженні встановлено, що за 7 годин після введення концентрації езомепразолу були мінімальними [7]. Отже, вища ефективність могла б бути за умови вищого дозування чи внутрішньовенного введення. У пуповині при народженні не виявлено езомепразолу. Це свідчить про те, що при цій пероральній дозі немає значного трансплацентарного пасажу.

Дослідження ІПП продовжуються, оскільки не отримано однозначних даних щодо ефективності застосування цих препаратів при прееклампсії, проте одержані дані вселяють надію на їх ефективність.

\section{Метформін та сульфасалазин}

Метформін - це пероральний гіпоглікемічний засіб, що застосовують для лікування діа- 
бету II типу та гестаційного діабету. Подібно до правастатину та ІПП, він також дозозалежно зменшує секрецію антиангіогенних факторів з плаценти. Він може пом'якшити дисфункцію ендотелію (зменшує експресію VCAM-1) і сприяти розширенню судин у маткових кровоносних судинах матері.

У рандомізованому дослідженні, проведеному [36], в якому вивчали потенціал метформіну в зменшенні приросту ваги матері та плода в жінок з ожирінням повідомили про зменшення частоти гестозів на 76\% $(\mathrm{OR}=0,24 ; 95 \% \mathrm{CI}=$ $0,10-0,61 ; \mathrm{P}<0,001)$. Порівнюючи метформін та інсулін, вчені дійшли висновку, що показники гіпертонічних розладів знижуються серед тих, хто отримував метформін $(\mathrm{n}=836 ; \mathrm{RR}=0,68$; $95 \%$ CI $=0,48-0,95)$. Проте в іншому дослідженні, в якому порівнювали метформін з плацебо [3], не виявили різниці в гіпертонічних розладах $(\mathrm{n}=609 ; \mathrm{RR}=0,86 ; 95 \% \mathrm{CI}=0,33-2,26$; $\mathrm{P}=0,76)$. Слід зазначити, що в жодному дослідженні з профілактики метформіну не оцінювали ризик розвитку прееклампсії як основний результат.

У великому когортному дослідженні, в якому оцінювали вплив, розвиток та емоційну сферу в дітей, довели безпечність метформіну для дитячого організму [21]. Недоліком застосування метформіну є високий рівень поширеності шлунково-кишкових побічних ефектів.

Також встановили, що сульфасалазин, протизапальний препарат для лікування запальних захворювань кишечника, зменшує плацентарну секрецію sFlt-1, збільшує фактор росту плаценти (PlGF) і зменшує дисфункцію ендотелію [5]. Потенційна перевага препарату полягає в тому, що його потужна протизапальна дія може допомогти вирішити плацентарне та системне запалення при прееклампсії. Однак досі проводять фармакокінетичні дослідження сульфасалазину серед жінок з передчасною прееклампсією. Існують інші малі молекули, щодо яких повідомляли про зменшення секреціï sFlt-1 (такі як софалькон, YC1 та уабаїн) [30], проте профіль їх безпечності потребуе поглибленого вивчення.

Антиоксиданти, рослинні екстракти та мікроелементи

Враховуючи роль окисного стресу в патогенезі прееклампсії, багато препаратів, які мають антиоксидантну дію, дослідники оцінювали щодо потенціалу цих засобів для профілактики або лікування прееклампсії. Дуже велике клі- нічне випробування [34] (n=10,154; RR прееклампсії у групі, в якій застосовували вітаміни, $=1,07 ; 95 \% \mathrm{CI}=0,93-1,24 ; \mathrm{P}=0,33$ ) розвіяло надію, викликану попереднім випробуванням, що антиоксиданти, вітамін С та Е запобігають прееклампсії.

Мелатонін - це природна сполука, що виділяється епіфізом, яка регулює циркадний ритм. Добре відомий антиоксидантними властивостями. У доклінічних дослідженнях встановили, що мелатонін знижує плацентарний окислювальний стрес і регулює молекули, які беруть участь в антиоксидантній реакції [16]. У невеликому дослідженні виявили, що застосування 10 мг орального мелатоніну (поділене на 3 рази на добу) 20 жінкам із передчасним гестозом продовжувало період гестації на $6 \pm 2,3$ доби та зменшувало потребу в антигіпертензивних препаратах [16]. Проте дослідження мелатоніну є нечисленними.

MitoQ - це невелика молекула, що випускається як харчова добавка, спрямована на окислювальний стрес у мітохондріях (основне джерело активних форм кисню, які спричинюють внутрішньоклітинний окислювальний стрес). На тваринних моделях встановили [26], що MitoQ зменшує окислювальний стрес плаценти та усуває гестоз на пізніх термінах вагітності. Цікаво, що його введення на ранніх термінах вагітності посилило фенотип прееклампсії. Це пов'язують з тим, що окислювальний стрес стимулює ранній розвиток плаценти.

Поліфеноли - це мікроелементи 3 антиоксидантними властивостями, що містяться в ягодах, квасолі, овочах, чаї, горіхах та червоному вині. Флавоноїди - це антиоксиданти, які надають фруктам та овочам яскравих кольорів. Додавання поліфенолу ресвератролу до плацентарного цитотрофобласту збільшує внутрішньоклітинні молекули, що беруть участь в антиоксидантній реакції, і зменшує секрецію sFlt-1 [14]. У багатьох дослідженнях на тваринних моделях довели, що численні мікроелементи та рослинні екстракти (включаючи поліфеноли та флавоноїди) також усувають прееклампсію [11,17,41].

Що стосується інших мікроелементів, то для профілактичного лікування пропонували добавки з високими дозами фолієвої кислоти, проте надалі ефективність цього методу спростували ( $\mathrm{n}=2464 ; \mathrm{RR}$ прееклампсії серед жінок, яким давали 4 мг фолієвої кислоти, = 1,10; 95\% CI = 0,90-1,34; P=0,37) [40]. Встановили, що нікотинамід (вітамін В3) зменшує вазокон- 
стрикцію та усуває прееклампсію [24]. Клінічні дослідження його ефективності досі проводяться.

Отже, мікроелементи та рослинні екстракти можуть стати предметом клінічних випробувань завдяки широкому застосуванню та високому профілю безпеки.

\section{Аферез}

Спочатку аферез запропонували як лікування прееклампсії у 2003 та 2006 роках з урахуванням того, що він виводив ліпіди, які викликають серцево-судинні захворювання. Починаючи з цих періодів, фокус лікування прееклампсії аферезом змістився до потенціалу виведення sFlt-1 з кровообігу. Після одноразового лікування за допомогою аферезу спостерігалося зниження рівня sFlt-1 у циркуляції на 15-28\% [37]. Крім того, ще 3 жінки проходили серійне лікування аферезу: циркуляція sFlt-1 тимчасово зменшувалася після кожного лікування, а вагітність тривала від 15 до 23 днів.

Аферез є інвазивним, тому досить складно провести великі клінічні випробування. Проте за відсутності інших ефективних методів цей може застосовуватися та знайти роль у лікуванні захворювань, які перебігають у дуже ранніх гестаціях, де можливості вкрай обмежені, а прогноз несприятливий [104].

\section{Моноклональні антитіла}

Моноклональні антитіла є досить ефективним класом препаратів для лікування гестозу, оскільки вони дуже специфічні та теоретично можуть зовсім не проникати крізь плаценту. Фактор некрозу пухлин альфа (ФНП- $\alpha)$ це цитокін, що підвищується при прееклампсії [26]. Вважають, що він відіграє важливу роль у прозапальній відповіді при прееклампсії. Етанерцепт - це злитий білок (застосовується клінічно для лікування ревматоїдного артриту), де частина рецептора ФНП- $\alpha$ зливається з постійною (Fc) частиною антитіла імуноглобуліну G. Рецептор ФНП- $\alpha$ на етанерцепті зв'язується з циркулюючим ФНП- $\alpha$ і нейтралізує його активність. У двох дослідженнях довели, що етанерцепт зменшує прояви прееклампсії [39].

Прееклампсія асоціюється 3 активацією комплементу, тому порушення цієї системи в моделях на мишах викликало клінічні ознаки прееклампсії [33]. Повідомляють про випадок, коли серійні дози інгібітора комплементу екулізумабу (рекомбінантного гуманізованого моноклонального антитіла (МВ), що призначають для гемолітично-уремічного синдрому) використовували для лікування пацієнтки на терміні вагітності 26 тижнів із синдромом HELLP. Після лікування їi біохімічні показники (включаючи значно погіршену функцію печінки та низьку кількість тромбоцитів), вагітність продовжено до 29 тижня. Ефективним також виявилося застосування препарату у разі відсутньої відповіді на лікування діалізом при гострій травмі нирок 3 порушенням функції [25]. Тому екулізумаб заслуговує на подальші дослідження в лікуванні прееклампсії, проте його мінусом є висока вартість.

Як альтернативний метод лікування запропонували фрагмент імунного антигензв'язуючого антигену (Fab), фрагменти імуноглобуліну, отримані від овець, застосовують для купірування токсичної дії дигоксину. Обгрунтування полягає в тому, що ендогенні глікозидні фактори блокують внутрішньоклітинні натрієві насоси в ендотелії, а це призводить до звуження судин. Імунний Fab до дигоксину блокує ці фактори. Ці дослідження виконуються поки на доклінічному етапі [20].

\section{Антитромбін III}

Рекомбінантний антитромбін III запропонували для лікування прееклампсії завдяки його протизапальним та антикоагулянтним властивостям. Проте багатоцентрове плацебо контрольоване дослідження у Сполучених Штатах Америки жінок з передчасним гестозом не виявило різниці в середньому збільшенні терміну вагітності (5,0 доби в досліджуваній групі та 6,0 доби в групі плацебо; $\mathrm{P}=0.95)$ [31]. Проте вчені продовжують дослідження в цьому напрямі, наразі в Японії зареєстровано нове рандомізоване дослідження іншого рекомбінантного препарату антитромбіну III.

\section{Фактор росту плаценти}

Введення плацентарного фактора росту (PlGF) може допомогти подолати втрату фактор росту ендотелію судин VEGF, яка нейтралізується циркулюючим sFlt-1. Це може відновити гомеостаз судин і стати способом лікування хвороби. Вчені створили тваринну модель прееклампсії, перев'язавши маткові артерії, таким чином викликавши плацентарну гіпоксію. Після введення PlGF зникла гіпертензія. Ці дослідження покладають велику надію, проте є надзвичайно високовартісними, адже досить складно збільшити виробництво цілих білків, таких як PlGF для застосування у людей.

\section{Короткі інтерференційні РНК}

Вчені почали застосовувати новітні технології короткої інтерференційної РНК (siRNA), 
спрямованої на sFlt-1. Метод полягає в тому, що ключовими молекулами в РНК є малі інтерференційні РНК та мікроРНК. Ці молекули можуть вступати у взаємодію із комплементарними послідовностями в інших молекулах РНК, наприклад у матричних РНК, і підвищувати або пригнічувати їхню активність. Фактично siRNA - це короткі ланцюги РНК, які використовують чинний внутрішньоклітинний механізм для зменшення експресії білків. Спеціально хімічно модифікували siRNA, націлені на sFlt-1. У дослідженнях на тваринах підтвердили зменшення експресії sFlt-1, зниження артеріального тиску та протеїнурію [38].

В іншому дослідженні інтерференційної РНК [13] вчені помітили, що шляхом зменшення ангіотензиногену зменшуються прояви прееклампсії, такі як протеїнурія, гіпертензія та затримки росту плода. Очевидно, що висока ефективність інтерференційної РНК пояснюється й тим, що при введенні в кровообіг вона поглинається печінкою, де і відбувається синтез ангіотензиноген. Це означає, що іiі можна просто ввести внутрішньовенно, і більша частка потрапить до печінки. Тому застосування малих ядерних РНК може стати перспективним напрямом у клінічних випробуваннях.

\section{Інші новітні методи}

Альтернативними методами лікування прееклампсії є застосування стовбурових клітин, проте дослідження в цьому напрямі перебувають лише на доклінічному етапі. [13]. Новітнім методом лікування прееклампсії може стати застосування біополімеру, що транспортує діючі речовини у судинах матері для інгібування системного запалення. Йдеться про пептидний фрагмент, який може утримувати активний препарат. Він інгібує NF-кB - так званий ядерний фактор «капа-бі», універсальний фактор транскрипції, який контролює експресію генів імунної відповіді та відіграє роль головного регулятора прозапальної реакції [10].

Таким чином, під час аналізу наявних альтернативних способів лікування та профілактики прееклампсії встановлено, що є ряд препаратів, які виявляють свою ефективність щодо патогенезу захворювання. Однак ці методи потребують подальших підтверджень.

Автор заявляе про відсутність конфлікту інтересів.

\section{References/Література}

1. Abalos E, Cuesta C, Grosso AL et al. (2013). Global and regional estimates of preeclampsia and eclampsia: a systematic review. European journal of obstetrics, gynecology, and reproductive biology. 170: 1-7.

2. Ahmed A, Williams DJ, Cheed V et al. (2020). Pravastatin for early-onset pre-eclampsia: a randomised, blinded, placebo-controlled trial. BJOG: 127: 478-488.

3. Alqudah A, McKinley MC, McNally R et al. (2018). Risk of pre-eclampsia in women taking metformin: a systematic review and meta-analysis. Diabet Med. 35: 160-172.

4. Ananth CV, Keye S KM, Wapner RJ. (2013). Pre-eclampsia rates in the United States, 1980-2010: age-period-cohort analysis. BMJ. 347: f6564. Antioxid Redox Signal: (Epub ahead of print).

5. Brownfoot FC, Hannan NJ, Cannon P et al. (2019). Sulfasalazine reduces placental secretion of antiangiogenic factors, up-regulates the secretion of placental growth factor and rescues endothelial dysfunction. EBioMedicine. 41: 636-648.

6. Carson RA, Rudine AC, Tally SJ et al. (2018). Statins impact primary embryonic mouse neural stem cell survival, cell death, and fate through distinct mechanisms. PLoS One: 13e0196387.

7. Cluver CA, Hannan NJ, van Papendorp E et al. (2018). Esomeprazole to treat women with preterm preeclampsia: a randomized placebo controlled trial. Am J Obstet Gynecol. 219: 388.e1-388.e17.

8. Costantine MM, Cleary K, Hebert MF et al. (2016). Safety and pharmacokinetics of pravastatin used for the prevention of preeclampsia in high-risk pregnant women: a pilot randomized controlled trial. Am J Obstet Gynecol. 214: 720.e1-720.e17.

9. De Alwis N, Beard S, Mangwiro YT et al. (2020). Pravastatin as the statin of choice for reducing pre-eclampsia-associated endothelial dysfunction. Pregnancy Hypertens: 20: 83-91.

10. Eddy AC, Howell JA, Chapman $\mathrm{H}$ et al. (2020). Biopolymer-delivered, maternally sequestered NF- $\mathrm{KB}$ (nuclear factor $-\mathrm{\kappa B}$ ) inhibitory peptide for treatment of preeclampsia. Hypertension. 75: 193-201.

11. Fushima T, Sekimoto A, OeY et al. (2020). Nicotinamide ameliorates a preeclampsia-like condition in mice with reduced uterine perfusion pressure. Am J Physiol Renal Physiol. 312: F366-F372.

12. Garrett N, Pombo J, Umpierrez M et al. (2018). Pravastatin therapy during preeclampsia prevents long-term adverse health effects in mice. $\mathrm{JCl}$ Insight: 3e120147.

13. Haase N, Foster DJ, Cunningham MW et al. (2020). RNA interference therapeutics targeting angiotensinogen ameliorate preeclamptic phenotype in rodent models. J Clin Invest. 130: 2928-2942.

14. Hannan NJ, Brownfoot FC, Cannon P et al. (2017). Resveratrol inhibits release of soluble fms-like tyrosine kinase (sFlt-1) and soluble endoglin and improves vascular dysfunction - implications as a preeclampsia treatment. Sci Rep. 7: 1819.

15. Hastie R, Bergman L, Cluver CA et al. (2019). Proton pump inhibitors and preeclampsia risk among 157720 women. Hypertension. 73: 1097-1103.

16. Hobson SR, Gurusinghe S, Lim R et al. (2018). Melatonin improves endothelial function in vitro and prolongs pregnancy in women with early-onset preeclampsia. J Pineal Res: 65e12508.

17. Huang J, Zheng L, Wang F et al. (2020). Mangiferin ameliorates placental oxidative stress and activates PI3K/Akt/mTOR pathway in mouse model of 
preeclampsia. Arch Pharm Res. 43: 233-241. Hypertension. 69: 457-468.

18. Kraker K, O'Driscoll JM, Schutte T et al. (2020). Statins reverse postpartum cardiovascular dysfunction in a rat model of preeclampsia. Hypertension. 75: 202-210.

19. Lai T, Wu M, Liu J et al. (2018). Acid-suppressive drug use during pregnancy and the risk of childhood asthma: a meta-analysis. Pediatrics: $141 \mathrm{e} 20170889$.

20. Lam GK, Hopate-Sitake M, Adair D et al. (2013). Digoxin antibody fragment, antigen binding (Fab), treatment of preeclampsia in women with endogenous digitals-like factor: a secondary analysis of the DEEP Trial. Am J Obstet Gynecol. 209: 119.e1-119.e.

21. Landi SN, Radke S, Engel SM et al. (2019). Association of long-term child growth and developmental outcomes with metformin vs insulin treatment for gestational diabetes. JAMA Pediatr. 173: 160-168.

22. Lefkou E, Mamopoulos A, Dagklis T et al. (2016). Pravastatin improves pregnancy outcomes in obstetric antiphospholipid syndrome refractory to antithrombotic therapy. J Clin Invest. 126: 2933-2940.

23. Leon LJ, McCarthy FP, Direk K et al. (2019). Preeclampsia and Cardiovascular Disease in a Large UK Pregnancy Cohort of Linked Electronic Health Records: A CALIBER Study. Circulation. 140: 1050-1060.

24. Li F, Fushima T, Oyanagi $G$ et al. (2016). Nicotinamide benefits both mothers and pups in two contrasting mouse models of preeclampsia Proc Natl Acad Sci USA. 113: 13450-13455.

25. Lokki Al, Haapio M, Heikkinen-Eloranta J. (2020). Eculizumab treatment for postpartum HELLP syndrome and aHUS-case report. Front Immunol. 11: 548 .

26. Matok I, Levy A, Wiznitzer A et al. (2012). The safety of fetal exposure to proton-pump inhibitors during pregnancy. Dig Dis Sci. 57: 699-705.

27. Mol BWJ, Roberts CT, Thangaratinam S et al. (2016). Preeclampsia Lancet. 387: 999-1011.

28. Onda K, Tong S, Beard S et al. (2017). Proton Pump Inhibitors Decrease Soluble fms-Like Tyrosine Kinase-1 and Soluble Endoglin Secretion, Decrease Hypertension, and Rescue Endothelial Dysfunction. Hypertension. 69: 457-468.

29. Onda K, Tong S, Beard S et al. (2017). Proton pump inhibitors decrease soluble fms-like tyrosine kinase-1 and soluble endoglin secretion, decrease hypertension, and rescue endothelial dysfunction.

30. Onda K, Tong S, Nakahara A et al. (2015). Sofalcone upregulates the nuclear factor (erythroid-derived 2)-like 2/heme oxygenase-1 pathway, reduces soluble fms-like tyrosine kinase-1, and quenches endothelial dysfunction: potential therapeutic for preeclampsia. Hypertension. 65: 855-862

31. Paidas MJ, Tita ATN, Macones GA et al. (2020). Prospective, randomized, double-blind, placebo-controlled evaluation of the pharmacokinetics, safety and efficacy of recombinant antithrombin versus placebo in preterm preeclampsia. Am J Obstet Gynecol: ([Epub ahead of print]).

32. Polsani S, Phipps E, Jim B. (2020). Emerging new biomarkers of preeclampsia. Adv Chronic Kidney Dis. 20 (3): 271-279.

33. Regal JF, Burwick RM, Fleming SD. (2017). The complement system and preeclampsia. Curr Hypertens Rep. 19: 87.

34. Roberts JM, Myatt L, Spong CY et al. (2010). Vitamins $C$ and $E$ to prevent complications of pregnancy-associated hypertension. N Engl J Med. 362: 1282-1291.

35. Saleh L, Samantar R, Garrelds IM et al. (2017). Low soluble fms-like tyrosine kinase-1, endoglin, and endothelin-1 levels in women with confirmed or suspected preeclampsia using proton pump inhibitors. Hypertension. 70: 594-600

36. Syngelaki A, Nicolaides KH, Balani J et al. (2016). Metformin versus placebo in obese pregnant women without diabetes mellitus. N Engl J Med. 374: 434-443.

37. Thadhani R, Hagmann H, Schaarschmidt W et al. (2016). Removal of soluble fms-like tyrosine kinase- 1 by dextran sulfate apheresis in preeclampsia. J Am Soc Nephrol. 27: 903-913.

38. TuranovAA, Lo A, Hassler MR etal. (2018). RNAi modulation of placental sFLT1 for the treatment of preeclampsia. Nat Biotechnol: ([Epub ahead of print]).

39. Warrington JP, Drummond HA, Granger JP, Ryan MJ. (2015). Placental ischemia-induced increases in brain water content and cerebrovascular permeability: role of TNF- $\alpha$. Am J Physiol Regul Integr Comp Physiol. 309: R1425-R1431.

40. Wen SW, White RR, Rybak $\mathrm{N}$ et al. (2018). Effect of high dose folic acid supplementation in pregnancy on pre-eclampsia (FACT): double blind, phase III, randomised controlled, international, multicentre trial. BMJ. 362: k3478.

41. Williamson RD, McCarthy FP, Manna S et al. (2020). L-(+)-ergothioneine significantly improves the clinical characteristics of preeclampsia in the reduced uterine perfusion pressure rat model. Hypertension. 75: 561-568.

42. Wu P, Haththotuwa R, Kwok CS et al. (2017). Preeclampsia and Future Cardiovascular Health: A Systematic Review and Meta-Analysis. Circ Cardiovasc Qual Outcomes: 10.

43. Yang Y, Xu P, Zhu F et al. (2020). The potent antioxidant MitoQ protects against preeclampsia during late gestation but increases the risk of preeclampsia when administered in early pregnancy.

44. Yebyo HG, Aschmann HE, Kaufmann M, Puhan MA. (2019). Comparative effectiveness and safety of statins as a class and of specific statins for primary prevention of cardiovascular disease: A systematic review, metaanalysis, and network meta-analysis of randomized trials with. 94, 283 participants. Am Heart J. 210: 18-28.

45. Zeisler H, LlurbaE, Chantraine Fetal. (2016). Predictive value of the sFlt1: PIGF ratio in women with suspected preeclampsia. N Engl J Med. 374 (1): 13-22.

\section{Відомості про авторів:}

Іщенко Ганна Іванівна - к.мед.н., н.с. відділення лікування та профілактики гнійно-запальних захворювань в акушерстві ДУ «ІПАГ імені акад. О.М. Лук'янової НАМН України». Адреса: м. Київ, вул. П. Майбороди, 8; тел. (044) 484-18-71. http://orcid.org/0000-0003-0700-4517.

Стаття надійшла до редакції 11.06.2021 р.; прийнята до друку 15.09 .2021 p. 